\title{
Kidd Mine - dealing with the issues of deep and high stress mining - past, present and future
}

\author{
DB Counter Glencore Canada Corp., Canada
}

\begin{abstract}
Kidd Creek Mine is the deepest active base metal mine in the world, extending to a depth of $3 \mathrm{~km}$ below surface. The mine operators and engineers have met the ongoing challenges of mining sublevel open stopes at extreme depth through the utilisation of cutting edge technology, while expanding on a knowledge base encompassing 48 years of continuous operation under increasingly difficult conditions. Methods of dealing with geotechnical, logistical, and environmental challenges will be discussed, and areas for future development or pure research will be suggested.
\end{abstract}

\section{$1 \quad$ Introduction}

Kidd Creek Mine has been in continuous operation since November 1966. The operation started as an open pit, which was supplanted by an underground operation, beginning in 1972. Sixty five million tons ( $\mathrm{m} t$ ) of waste and $30.5 \mathrm{~m}$ t of ore were recovered from the open pit by the time the last blast was taken in 1977 .

Clearing of overburden for the No. 1 Shaft and the development of the service ramp portal began in May and July 1969 respectively. The No. 1 Shaft reached a depth of 930 m below surface on 13 March 1972; exactly two years to the day after the start of sinking. The crusher was commissioned on the 2800 Level in June 1973. Production concluded in 2011, after a total of $71.5 \mathrm{~m} \mathrm{t}$ of ore had been recovered between the pit floor and the 2600 Level. The mineable portion of the remaining $0.6 \mathrm{~m} \mathrm{t}$, or $0.8 \%$ of the mineral resources, cannot be recovered until the end of mine life due to the potential of a wedge failure within the mine foot wall.

Development of the No. 2 Shaft, to access reserves between the 2600 and 4600 Levels (closest nominal level elevation in feet below surface) began in 1974. No. 2 Mine was the first metric mine in Canada, where all lateral and vertical development, stopes, support systems, and fill were designed in metric units, unlike the No. 1 Mine, which was designed fully in imperial units. No. 2 Shaft was completed to a depth of 1,556 m below surface in September 1977. The crusher was located on the 4700 Level, and skipping occurred from the bottom of the fine ore bins on the 4900 Level. Mining commenced in 1978 from the 2800 Level, and production from No. 2 Mine was completed in 2005, after the recovery of $17.9 \mathrm{~m} \mathrm{t}$, representing $100 \%$ of the mineral reserves. The No. 2 Mine crushing and hoisting facilities have also been used to process ore from lower in the mine (No. 3 and D Mines), and were used for a period of time to process No. 1 Mine ore during the conversion of ventilation infrastructure, prior to the re-establishment of a mid-shaft loading pocket at the 2800 Level in No. 2 Shaft, tied to the No. 1 Mine crusher.

No. 3 Mine was initially developed by ramp beginning in January 1989 below the No. 2 Mine workings, as a result of ongoing exploration conducted from the 4600 Level, down dip of the upper portion of the mine. The No. 3 Shaft winze hoist room was completed in December 1989 just above the 4600 Level, and the shaft was sunk from the 4700 Level to access reserves from the 4600 to 6800 Levels, bottoming out at 2,105 $\mathrm{m}$ below surface in mid November 1991. The No. 3 Shaft hoisting facilities were shut down with the commissioning of the No. 4 Shaft, and the No. 3 Shaft was subsequently converted to a dedicated cooled air intake. Production began in 1990, and a total of $18.8 \mathrm{~m} \mathrm{t}$ or almost $97 \%$ of the reserves have been recovered to date from No. 3 Mine. Production is expected to be completed above the 6800 Level by mid 2016, with the exception of a few remnant pillars which are tied to the secondary extraction sequence in upper Mine $D$, and a number of stopes which are very close to the main ventilation infrastructure on the 6000 Level, which will be recovered very late in mine life. 
Diamond drilling continued from exploration sites on the 5200,6800, and No. 3 Shaft bottom access ramp elevations, resulting in pre-feasibility studies for the deep mine (Mine D, or No. 4 Mine) being prepared during the latter half of the 1990s. Board approval was granted for the development of Mine D in 2000, and preproduction development and shaft sinking were completed by 2006 to a depth of 3,014 m below surface. Twin hoist rooms were developed on the 4400 Level, housing two identical double drum hoists for the skips and main service cage, to allow the most effective use of capital spares and to facilitate maintenance. First ore production out of Mine D occurred in 2004 from the 7300 Level. To date, $12.1 \mathrm{~m} \mathrm{t}$ has been recovered from Mine D; representing $49 \%$ of the reserves. The current life-of-mine plan indicates production will continue until approximately 2021.

By incrementally extending the mine to depth over time, significant knowledge of the behaviour of the rock mass was gained prior to the design of the next stage of the operation. At the same time, progress in modelling and monitoring technologies, excavation techniques, and new ground support systems provided tools for the engineering and operating departments to deal with the changing response of the rock mass to mining, allowing the very high extraction ratios noted above. Concurrently, monitoring of the working environment, rock mass temperatures, and ventilation modifications necessary to support the ever expanding working zones, have led to major changes in the infrastructure to support mining at depth, including the use of passive inlet-air heat transfer systems, supplanted by mechanical refrigeration.

The increasing distance to the production areas and the more difficult working environment have led to the progressive adoption of automated production technologies with time, beginning with remote rock breaking with operators stationed centrally underground, then to remote rock breaking and conveying with operators stationed on surface, and ultimately to remote control systems for both the No. 3 and 4 shafts, where the hoists operate from surface. Recently, fully autonomous LHD technology has been introduced, and was rapidly expanded from solely transfer operations between fixed loading points at the bottom of the ore passes to the top of the mechanical rock breaker and grizzly equipped ore bins, to include remote mucking of active stopes to help reduce production delays associated with proactive restrictions to mitigate seismic hazard and allow blast gases to be removed from the workings, and to improve productivity.

Improvements in communications technology, including fibre optics and wireless networks have allowed near real time monitoring of rock mass deformation, and have opened the opportunity for the piggybacking of other technology, including personnel location, collision avoidance, human and machine interaction, and ventilation on demand to continue to reduce risk and improve worker safety.

Areas where future research and development work would be warranted include methods or techniques to quantify global rock mass deformation over time, including the response of the fill to the closure of the rock mass, in order to provide calibration data for numeric stress models. Current cutting edge technology, based on mobile three-dimensional laser-based surveying systems used to map the deformation of large transects of lateral development, is still hampered by the potential for local site specific strain of the surface of the mine openings masking or confounding the global strain within the rock mass surrounding the deposit. This local deformation is also affected by the interaction with the ground support systems in place within the excavations, compounded by changes to those systems over time (corrosion, yield, rehabilitation and the installation of new support coupled with the removal of damaged rock, etc.). The local displacement of the opening surfaces may also be significantly larger than the regional strain associated with mining, particularly if the development is distal to the mining zone, and within rock which is weaker than the regional stresses at depth. 


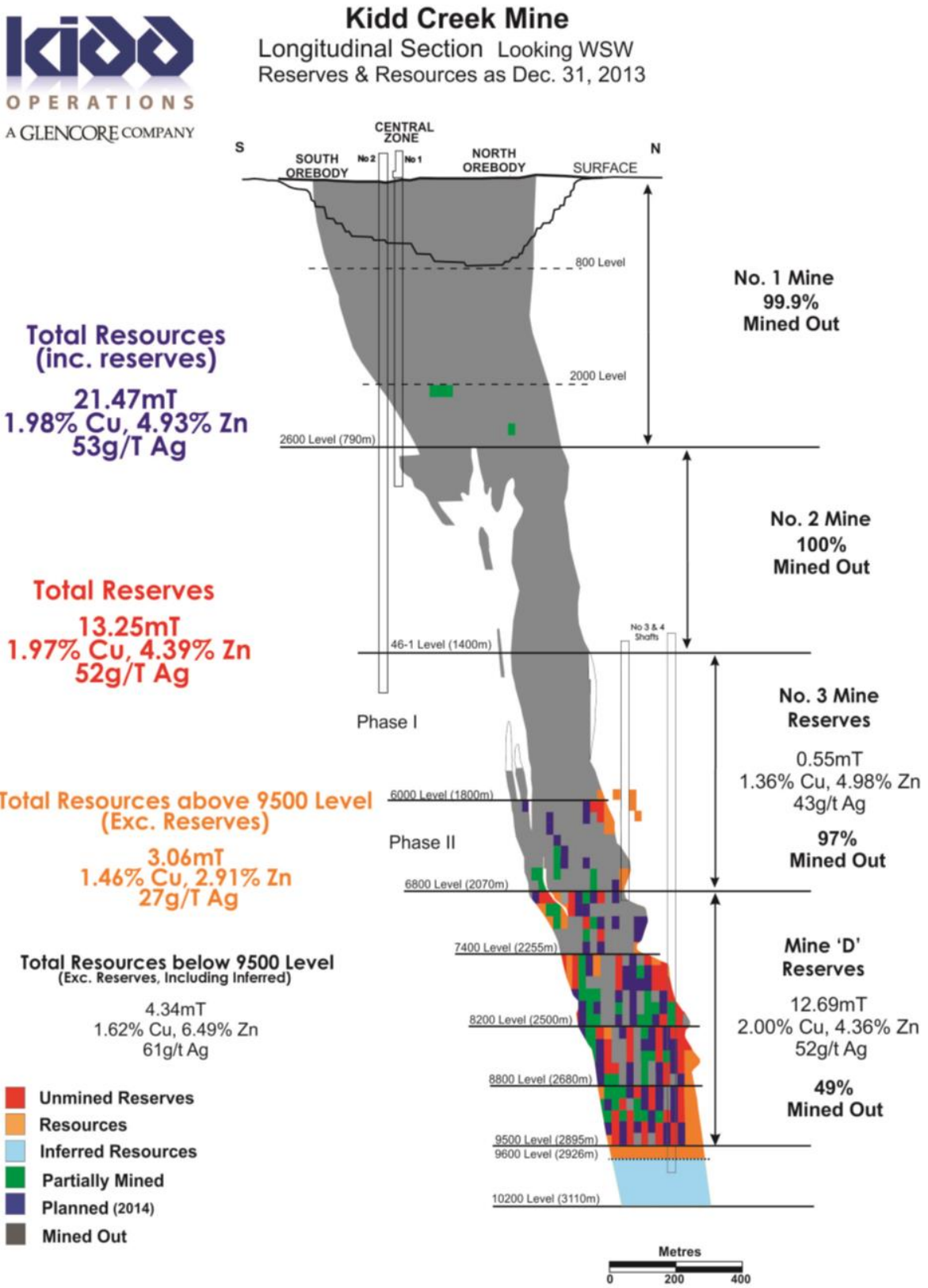

Figure 1 Kidd Creek long section, showing extent of historical mining and reserves

Passive seismic tomography potentially offers another tool to measure the response of large (mine scale) volumes of rock, however, the exact correlation between regional rock mass deformation and change in seismic velocity is unknown, and requires further investigation. Due to the huge volumes involved, concurrent statistically relevant measurements of local deformation are usually not available in sufficient numbers, or in the proper three-dimensional orientations to either confirm or deny the underlying deformation potentially associated with the change in seismic velocity. Deformation and irreversible degradation of the host rock mass should be fairly consistent over time and generally should be directed into the extracted volume on a mine scale. However, the rate of deformation in any given location could be highly variable, as it would be influenced by both the distance to the bulk excavation volume, properties of the rock mass within and between points of measurement, and the support density provided to any given stope or other mine opening to which the change is attributed (most significantly due to changes in the properties of the fill with ongoing deformation, and with changes in confining pressure as adjacent blocks are removed). The presence of significant regional, as well as local scale geologic structure, plus local topology changes in the distribution of varying lithologic units will also have a confounding effect. Due to 
the frequently limited nature of diamond drilling extending into the far field within the barren host rock, the three-dimensional location of changes in lithology, structure, etc. are also difficult to identify to the level of detail sufficient to calibrate the tomographic and stress models. These problems will not be resolved in the short term, but are areas requiring ongoing study.

\section{Geotechnical challenges and opportunities}

Kidd Mine has historically been actively involved in a number of geotechnical research initiatives, and has worked with both government agencies, and with academia to develop a number of tools to assist in the design and monitoring of mine infrastructure, and to better understand the properties and behaviour of the rock mass, support elements, and backfill.

\subsection{Hanging wall failure, 1997}

Very early on, the Kidd pit was used as a testing ground for the monitoring of pit stability, and the use of deep extensometers to verify the response of the pit to mining. Much of this work was done in conjunction with Natural Resources Canada (CANMET 1977) as part of the development of the 'Pit Slope Manual'.

Monitoring was begun in the early 1970s, through the use of prisms mounted on the pit walls in vertical arrays, spaced approximately $50 \mathrm{~m}$ apart along the pit benches. These monitoring locations continued to be surveyed on a monthly, and ultimately, quarterly basis through the mid 1990s, providing a database spanning more than two decades. A number of stations were lost due to local rockfalls, and the deterioration of the prism reflector coating over time, but key locations continued to be maintained as long as safe access was available. Over the intervening time frame, deformation of the pit wall on the order of up to a metre was locally observed, as the mine transitioned from an open pit to underground operation. Through the 1980s as the extraction of No. 1 Mine advanced, a very gradual acceleration in movement was noted, in conjunction with seasonal changes due to temperature, and at the same time, small cracks began to appear on surface along pre-existing geological discontinuities in outcrops beyond the pit crest. These cracks were also locally monitored with deformation gauges. As the level of extraction increased through the mid 1990s, and the last remaining yielding secondary pillars began to be mined, more significant acceleration of the surficial deformation became evident.

In the summer of 1997, after $88 \%$ of the reserves in No. 1 Mine had been recovered, a modest change in the rate of movement of the pit crest was observed, amounting to approximately $6 \mathrm{~cm}$ over the course of several months. Reading frequencies were increased, and coupled with observations of increasing deformation underground to depths approaching $600 \mathrm{~m}$, it became apparent that an incipient large scale failure was occurring in the hanging wall of the pit, extending into the underground workings. The failure has been described previously (Board et al. 2000). The rock mass failure resulted in the loss of access to the hanging wall of the orebody over nine levels, the loss of five main fill distribution conveyor systems, most of the hanging wall sump and dirty water pumping systems, and two secondary exhaust raises above the 2000 Level. The site was proactively closed for four days during the event.

Through the use of manual (and ultimately automated) survey monitoring of the pit slopes, and three-dimensional distinct element modelling, the failure was analysed and found to be the result of a very steep sided wedge subsiding into the underground workings, essentially down dip of the plunge line of the intersecting structures. It was determined that similar failure was possible in other quadrants of the pit, based on the presence of major steeply dipping structure, which could negatively impact significant elements of the mine infrastructure, including the shafts, ramp, and ventilation raises. As a result, the mining strategy was changed within the No. 1 Mine to restrict both the size and number of openings active at any given time, to minimise load and deformation rate changes and maintain confinement of the last remaining central yielding pillar supporting the foot wall. High risk stopes identified through the model were deferred until very late in mine life to reduce the risk of failure. Since the failure of the hanging wall in the No. 1 Mine, a total of $7.8 \mathrm{~m} \mathrm{t}$ of ore were recovered over a period of approximately 13 years, representing another $11 \%$ of the reserves, with no significant deformation of the foot wall or critical 
yielding of the core buttressing pillar noted. One period of accelerated movement in early 2001 was associated with the breaching of the last minable secondary pillar, which carried a low risk to the foot wall. Data from the failure back analysis was used to bracket the intact rock mass and fault properties, and those values were subsequently used in analysis of deeper portions of the mine, coupled with structural mapping, and in situ stress measurements. From Figure 2, it can be seen that the rate of deformation was nearly constant following the major slip episodes; however, it did slow very slightly with time, as the $150 \mathrm{~m}$ thick mass of consolidated rockfill at the base of the wedge was compressed against the foot wall. The primary monitoring point on the crest of the pit, centred in the wedge, was lost in June 2013 due to a local fall of ground, as the bulk of the failing mass has broken up due to ever-changing internal strains, coupled with precipitation and freeze thaw effects.

More recently, photogrammetric methods, LiDAR, as well as space borne radar interferometry have been investigated as additional tools which can be used to monitor the deformations on surface associated with the pit and underground workings, to a high degree of accuracy. Photogrammetric mapping of the pit slopes was used to establish the most predominant failure planes for use in additional modelling of the pit and upper mine pillar interactions, and to establish the zones of failure during follow-up investigations in 2010 used to define the long term mining plan for the No. 1 Mine. LiDAR surveys have been performed from multiple locations around the pit crest, and will be done annually to establish the rate at which the walls are deteriorating, as part of the finalisation of the mine closure plan. Space borne radar data was limited in historic extent (prior to and immediately after the 1997 failure), and due to the extremely large deformation associated with the hanging wall wedge failure over a very short time interval, it was impossible to reconcile the magnitude and extent of true displacement, as it greatly exceeded the typical wavelengths of the radar, making the development of a long term historic deformation assessment based on interferometry impossible. Over shorter time frames, and using dedicated data, this technology has merit to monitor regional changes, which could be extremely difficult to detect using traditional total station, ground, or airborne LiDAR surveying technology.

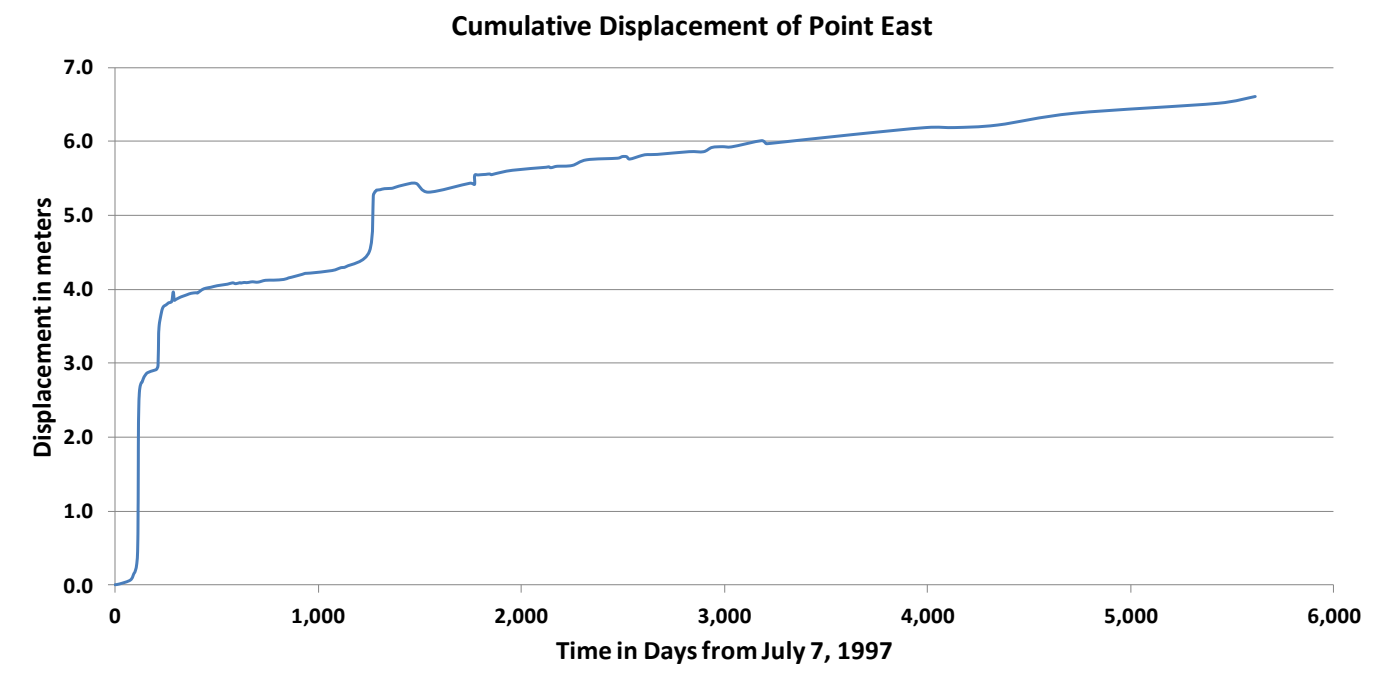

Figure 2 Displacement trace of survey monument Point East, since onset of accelerated hanging wall failure in July 1997. The Point East survey monument was lost during a local ground fall in June 2013 


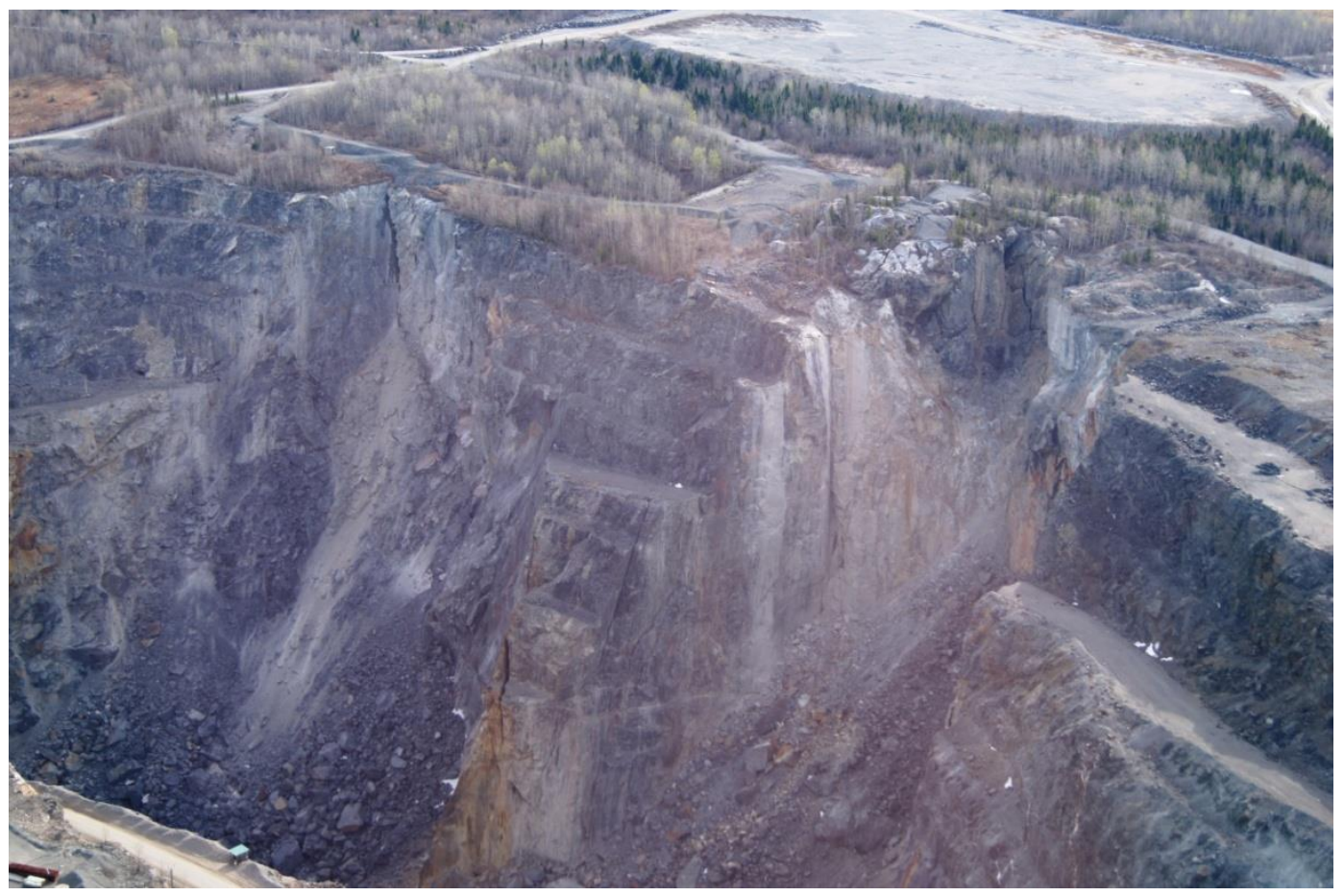

Figure 3 Hanging wall wedge 1997 failure zone, as photographed on 10 May 2013. Failure extends from embayment in pit wall at right, to near vertical structure in left background. Point East monitoring station on top of outcrop, in upper right near pit crest, failed due to undercutting in June 2013. Note tensile splitting of nose of wedge due to high imposed stresses caused by displacement towards the foot wall

\subsection{Mine seismicity}

Kidd Mine has historically been much less seismically active than comparably sized mines in the Canadian Shield, and worldwide. Much of this was attributed to the shape of the ore zone, which approaches that of a very steeply inclined flattened cylinder dipping at $75^{\circ}$, and the practice of mining in a primary/secondary retreat method, working outwards from the centre of the hanging wall towards the abutments and the foot wall, while advancing mining in blocks comprising up to five levels, each up to $40 \mathrm{~m}$ high, in a tetrahedral pattern upwards. Sills were intentionally mined through as soon as practical to avoid the concentration of stress and smooth the overall rock mass deformation profile over time. Kidd has also been relatively free of strainbursting, or the rapid release of energy from freshly exposed rock surfaces in development headings, due to the increasing amount of structure and closely spaced parting surfaces associated with the rock mass fabric with depth, and the relatively low rock mass strength as compared to the local stress field.

The first occurrence of a pillar burst, occurred in the mid 1980s on the 1600 Level. It was the result of the creation of a squat pillar in the drawpoint of a stope, under high vertical load, in massive sphalerite. Once the risk of bursting was recognised, the mine installed a source location 64 channel microseismic system in 1986, expanded that with a further 32 channel system in 1990, and ultimately converted to full waveform monitoring in the mid 1990s. Kidd is currently in the process of amalgamating two microseismic monitoring networks spanning 1,200 vertical metres of mine infrastructure with five strong ground motion sensors spanning nearly 1,600 vertical metres into one integrated monitoring network, to greatly improve overall dynamic range. Kidd has also adopted state of the art analysis techniques over time, to improve the means with which seismic data is assessed, in an effort to improve safety through the reduction of exposure, and to enable better use of the data in the determination of support design (Disley 2014).

The mine has experienced several damaging fault slip bursts over time, the first of which occurred in the mid 1980s in No. 1 Mine. More recent events, occurring between the 7000 and 7500 Levels of Mine D have been shown to be related to the release of imbalanced stored strain energy associated with both sills, and 
with the concurrent mining of a satellite ore lens, located well into the mine foot wall. By effectively deepening the hanging wall to foot wall distance (in plan view) through the mining of the satellite lens, the amount of deformation energy available increased substantially. It is interesting to note that the first major burst in the mine, which occurred around the 2600 Level, causing damage over seven levels in lower No. 1 Mine and upper No. 2 Mine occurred at the southern end of the main ore zone, at roughly the same time that another satellite ore zone was being mined well into the mine foot wall.

Following significant bursting in 2004, and with the advent of new tendons capable of withstanding high dynamic loads, the support systems in select areas of the mine were upgraded to include $1.8 \mathrm{~m}$ wide by $3 \mathrm{~m}$ long welded wire mesh (WWM) sheets, comprised of $4.82 \mathrm{~mm}$ wires on $100 \mathrm{~mm}$ centres in both directions, installed with $2.24 \mathrm{~m}$ long by $22 \mathrm{~mm}$ diameter threaded rebar on a $1 \mathrm{~m}$ square pattern, and horizontal $7.77 \mathrm{~mm}$ wire mesh straps, $0.3 \mathrm{~m}$ wide by $2.7 \mathrm{~m}$ long, using $2.24 \mathrm{~m}$ long modified cone bolts (MCB 33) on a $1.4 \mathrm{~m}$ vertical by $0.8 \mathrm{~m}$ horizontal pattern. The upgraded supports were generally located adjacent to major structure, and in the southern abutment of the ore zone, where historic activity had been located.

On 6 January 2009, a $M_{N} 3.8$ burst occurred on or about the 7000 Level near the southernmost limit of mining in the main ore zone, causing significant damage to multiple levels of the upper portion of Mine $D$, and lower 3 Mine. Damage was most significant in intersections which were not heavily reinforced at the time of capital development. Areas where dynamic rated support had already been installed fared much better. The event occurred along an incipient shear surface following a poorly defined joint set, linking the main ore zone mining to the satellite lens in the foot wall. Several subordinate surfaces, with the same strike and dip as the main rupture plane, also showed signs of movement. The structures were spaced roughly $20 \mathrm{~m}$ apart on centre, and dipped $65^{\circ}$ to the west-northwest. The frequency and attitude of the structures was such that they intersected the next crosscut to the north on the level $40 \mathrm{~m}$ below (crosscuts also spaced $20 \mathrm{~m}$ apart), increasing the number of free surfaces into which the moving blocks could displace. Since the structures were also slightly oblique to the long axis of the crosscuts, the amount of damage in the crosscuts was significantly higher than that in the foot wall development.

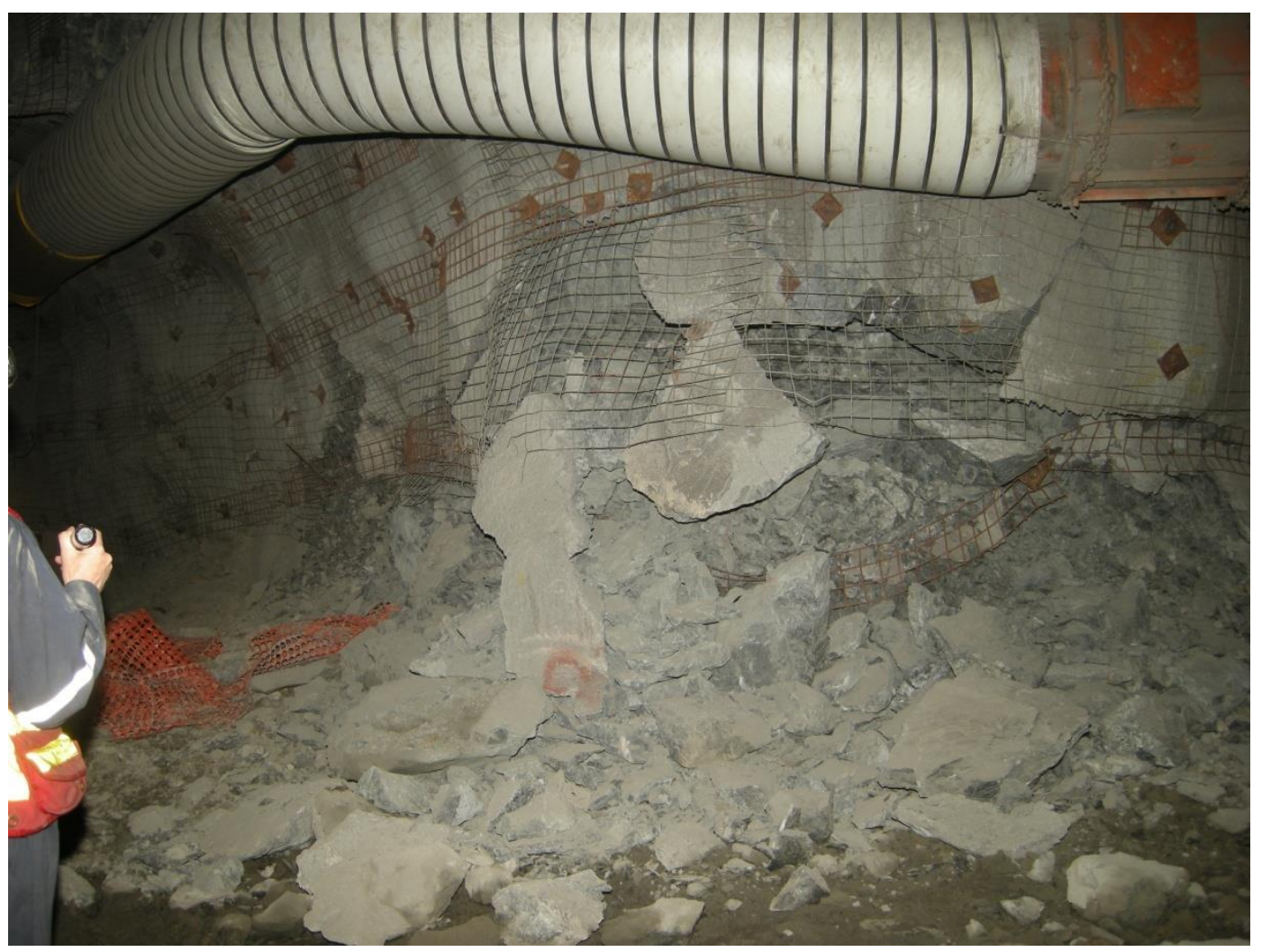

Figure 4 Damage at entrance to 70-82 XC from 6 January $2009 M_{N} 3.8$ event. Note damage concentrated near unsupported floor. Dynamic support installed through straps 
Repairs took approximately 18 months to complete, and upon resumption of mining, another $M_{N} 3.8$ event occurred on 13 September 2011, in almost the same location as the event of 2009, on the same poorly developed incipient structure. Damage during the second event was significantly reduced as compared to the first large event, as the density and type of support were modified during the 2009-2010 repairs to better withstand future events of similar magnitude. The newer support included $2.24 \mathrm{~m}$ long friction stabilisers and both 2.24 and $3.7 \mathrm{~m}$ long high strain expandable bolts (in areas of highly broken ground where traditional resin based tendons could not be installed), together with closer bolting patterns resulting from additional $2.24 \mathrm{~m}$ by $22 \mathrm{~mm}$ rebar installed during the repair process, through $4.82 \mathrm{~mm}$ mesh, and closely spaced $2.24 \mathrm{~m}$ modified cone bolts through $7.77 \mathrm{~mm}$ straps in two directions. Where necessary, fibre reinforced shotcrete had been applied over heavily damaged areas prior to bolting and screening to return the development to nearly the original profile. All intersections were also reinforced with both $3.7 \mathrm{~m}$ long expandable friction bolts, and 10-15 m long twin plain strand plated cable bolts, also interlaced with $7.77 \mathrm{~mm}$ mesh straps in two directions, on $1.5 \mathrm{~m}$ spacing. Where the ground in the intersection roof was too damaged to allow cable bolts to be installed, self-drilling R32S soil anchors (continuously threaded hollow core rebar), were installed up to $9 \mathrm{~m}$ into the back, and were grouted in place using neat Portland cement grout. Straps were also installed between the soil anchors. All suspect surfaces were re-bolted, due to the unknown integrity of the original support.

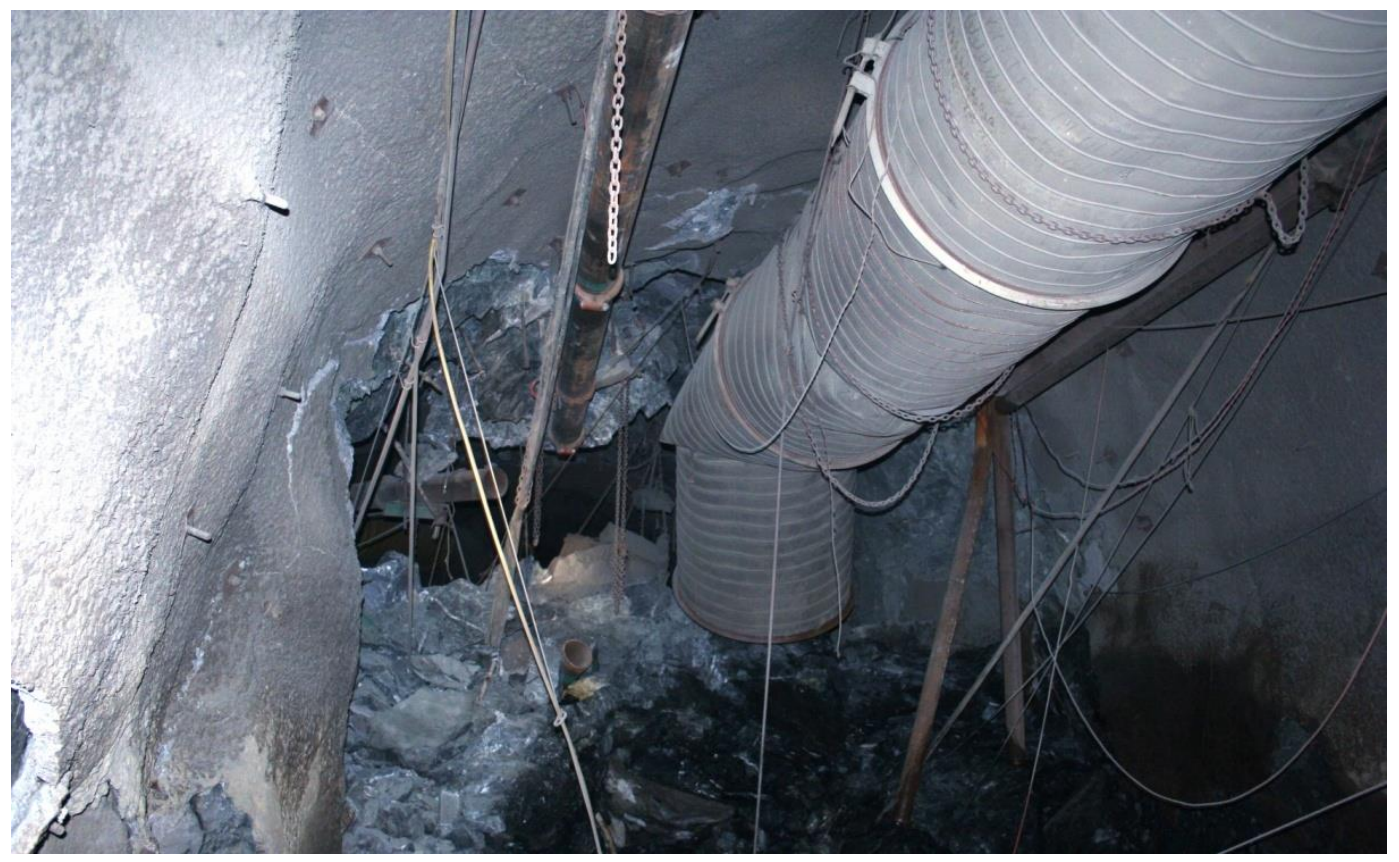

Figure 5 Damage to 71-01 Dr South at the intersection with 71-84 XC, 6 January 2009. Rupture plane cuts across back at end of truncated piping/vent duct. Original support comprised of $2.24 \mathrm{~m}$ rebar on $\mathbf{1 . 5} \mathrm{m}$ square pattern over shotcrete, with widely spaced single strand $4.5 \mathrm{~m}$ long spin cables

After both events, several consulting firms were contacted to run numerical models or to update existing models to try and determine the underlying factors responsible for the events, and to better understand the ability of the system to reload in such a short time period, with essentially very little production extraction between events. Both distinct element and Abaqus-based finite element models were created, and the underlying mechanism was determined. After the event of 13 September 2011, the mining of the satellite lens was put on hold, and a total of 12 different mining sequences were tested using the models to determine if the risk of damaging seismicity could be reduced by modulating the rate of overall deformation and hence energy release. The initial model runs of unique sequences were used to determine the overall effectiveness of the proposed change, based on smoothing the energy release rate over time. Sequences which showed no benefit, or an increase in energy release rate per tonne mined in the short term, were discounted early in the process. Model sequences which showed promise were then 
investigated in further detail, including multiple variants in the timing of certain mining blocks to determine overall strategy. As a result of this extensive work, it was determined that mining the satellite lens too early, while there was still significant stored strain energy in the main ore zone foot wall, was a potential trigger to the sudden slip of the foot wall on nascent structures (poorly defined joint sets), into the main ore extraction zone. By leaving the satellite lens until very late in mine life, the available energy which could be released in the form of damaging seismicity is anticipated to be reduced due to the ongoing deformation of the foot wall into the mined out main ore zone. As part of the refinement process of the most likely options, select panels were left as temporary or semi-permanent yielding pillars, to further limit the local rate and magnitude of foot wall deformation.

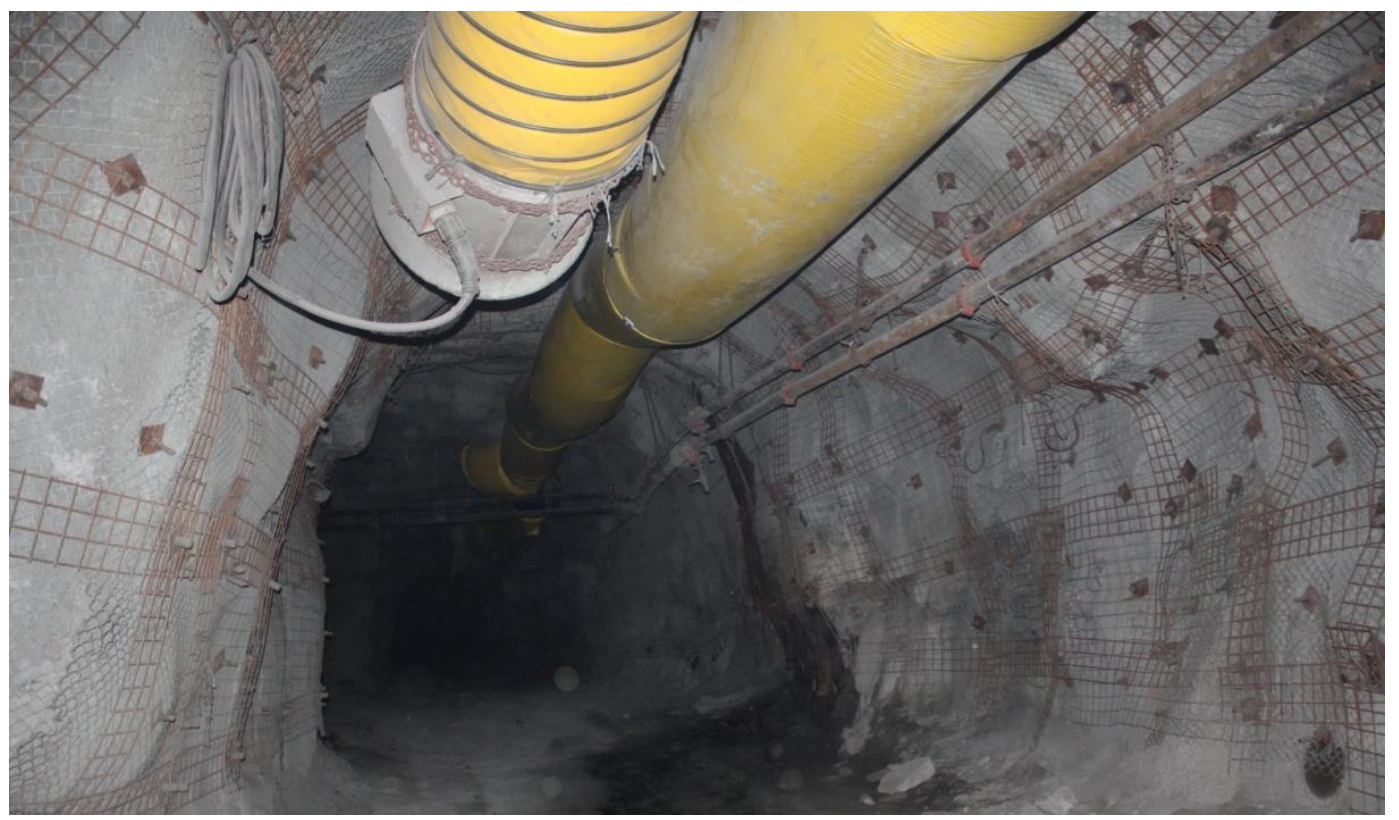

Figure 6 71-01 Dr South at 71-84 XC intersection, facing south, after repair. Rupture plane located at embayment on right. Temporary post out of field of view on left. Note use of $4.5 \mathrm{~mm}$ chain link fencing and $\mathbf{4 . 8 2} \mathrm{mm}$ WWM over shotcrete, with various tendons

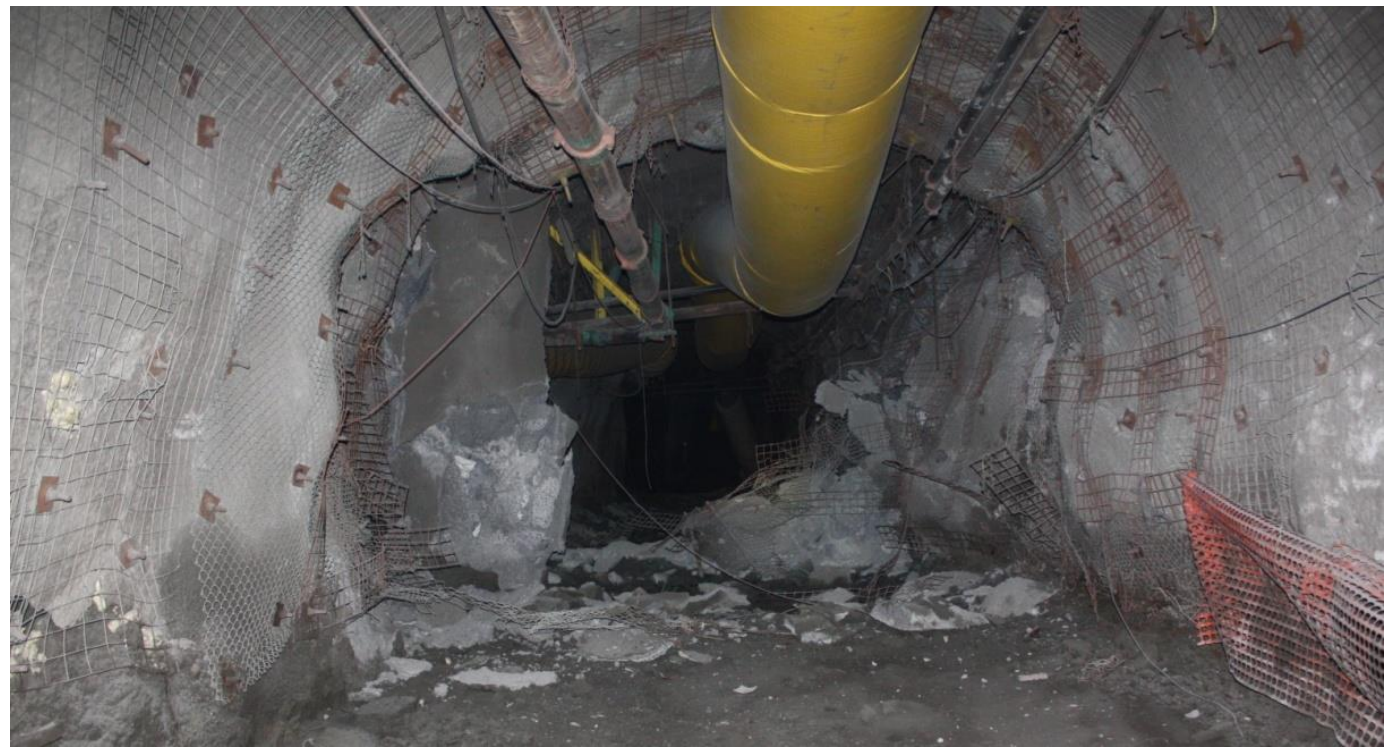

Figure 7 71-01 Dr South at the intersection with 71-84 XC, looking south, following second $\mathrm{M}_{\mathrm{N}}$ 3.8 event of 13 September 2011. Note the damage to the stiff shotcrete post used to temporarily support the intersection back until permanent ground support tendons were installed. Note limited damage to western wall in the immediate vicinity of the 
rupture surface, at the embayment in Figure 6. Damage concentrated near floor, which is not supported

This approach cannot totally eliminate the risk of seismic energy release, as to do so would require the cessation of extraction (mining) which creates the voids into which the host rock can deform, or which changes the level of confinement on critically oriented structure. Understanding the potential for high levels of energy release through detailed modelling, increasing the level of support in the higher risk areas, and proactive closures following blasting to allow sufficient time for the rock mass to strain prior to allowing personnel to re-enter the area are therefore the primary means to control the hazard.

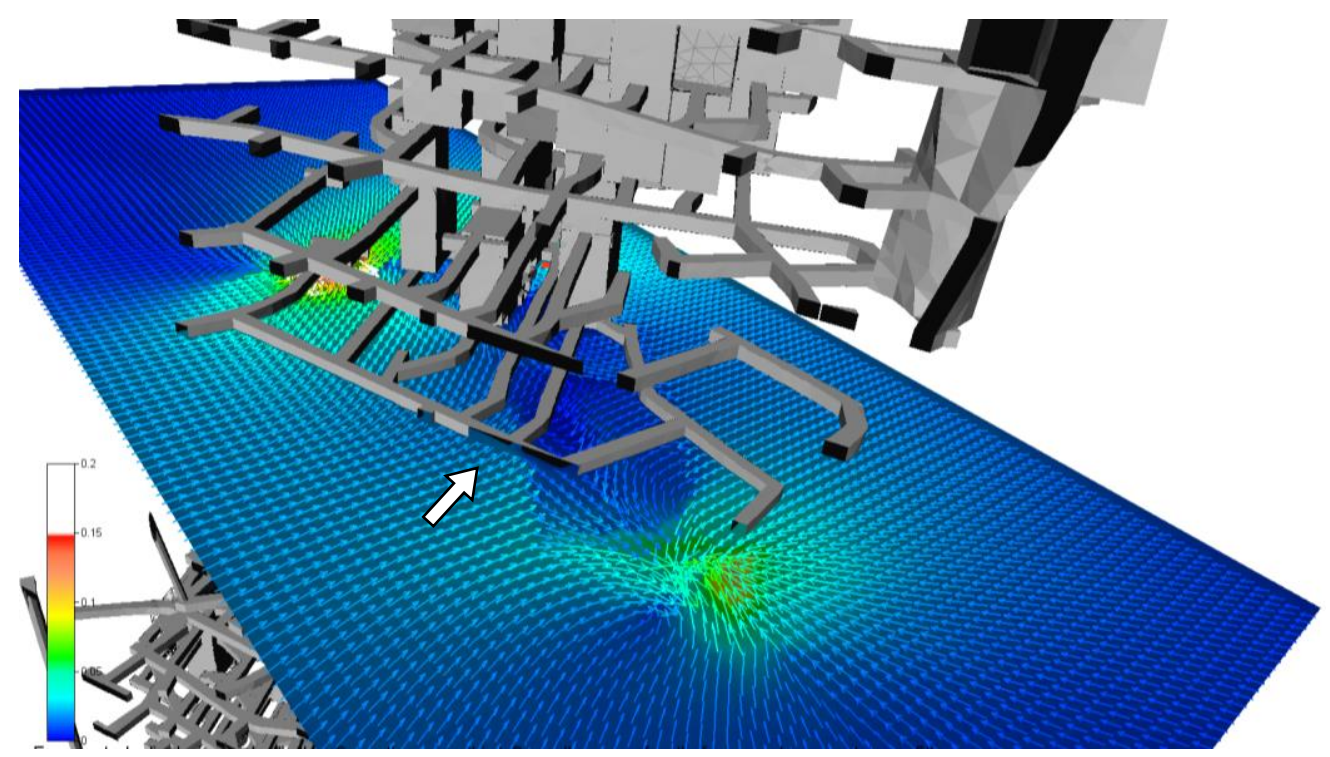

Figure 8 Forensic 3D strain softening dilatent explicit finite element model of the $2009 M_{N} 3.8$ rockburst. The slip surfaces (primary and subordinate) are defined by the major change in vector orientation, and magnitude in the centre of the image. Local effect of unclamping in the foot wall caused by the mining of a stope in the satellite lens (hidden from view in foreground, but located at point of high vector concentration in centre of figure) was likely a trigger to the coalescence of the slip surface. Movement of the main foot wall north of the primary slip surface (left) is oriented east-west, into the main ore zone mining void. Figures 4 and 15(a) are of the nose of the pillar at the point of intersection with the slip surface in Figure 8, at arrow

\subsection{Investigation of the deformation of ground support}

In the deeper parts of the mine, where there is not only the potential for seismicity, but also a high degree of strain associated with the creation of new openings, modifications have been made to the primary support strategy to further reduce the risk and the overall life-cost of support. Newer generation dynamic and high strain capacity bolts (Li 2010) are now almost exclusively used below the 8800 Level, and in highly deforming pillars and abutments above the 8800 Level to deal with the high rates of strain within the ore zones. Standard threaded rebar, with continuous ribs along the length of the bar which limit slip, proved to be too stiff to accommodate the high deformations associated with lateral development in the severely overstressed and highly schistose rhyolites which host the ore at depth. Failure of the thread roots and nuts due to the high levels of strain was observed to occur within one or two days of installation, and frequently an entire round would need to be re-supported due to the amount of deformation induced in the surfaces of the opening when the subsequent round was blasted.

Instrumentation installed to monitor the effectiveness of different ground support tendons in the deeper portion of the mine has revealed other deformation linked to the mining of stopes up to several hundred metres away. Four extensometers, each $15 \mathrm{~m}$ long, were installed sub-horizontally in the walls of a drift in 
the ore, in the northern abutment on the 9100 Level. Two extensometers were installed in each wall, on opposite sides of the drift, approximately $10 \mathrm{~m}$ apart, immediately beside support tendons. The extensometers initially showed slight convergence, due to the shrinkage of the high strength grout used to install them. As blasting of proximal stopes occurred, subtle movement has been revealed, occurring not only at the collar, but beyond the depth of the bolts, as the rock mass is deforming towards the mined openings. All four instruments are showing similar response, however, those instruments installed in the south-eastern wall of the crosscut, closest to the active stopes and structure, are showing the highest response. Instruments located in the northwest wall of the crosscut are showing substantially less response, as the void of the crosscut is shielding or interrupting the global deformation of the rock mass towards the stopes. The correlation with blasting is clearly evident in Figure 9.

Extensometer Data - Unit 101171003, 91-110 XC

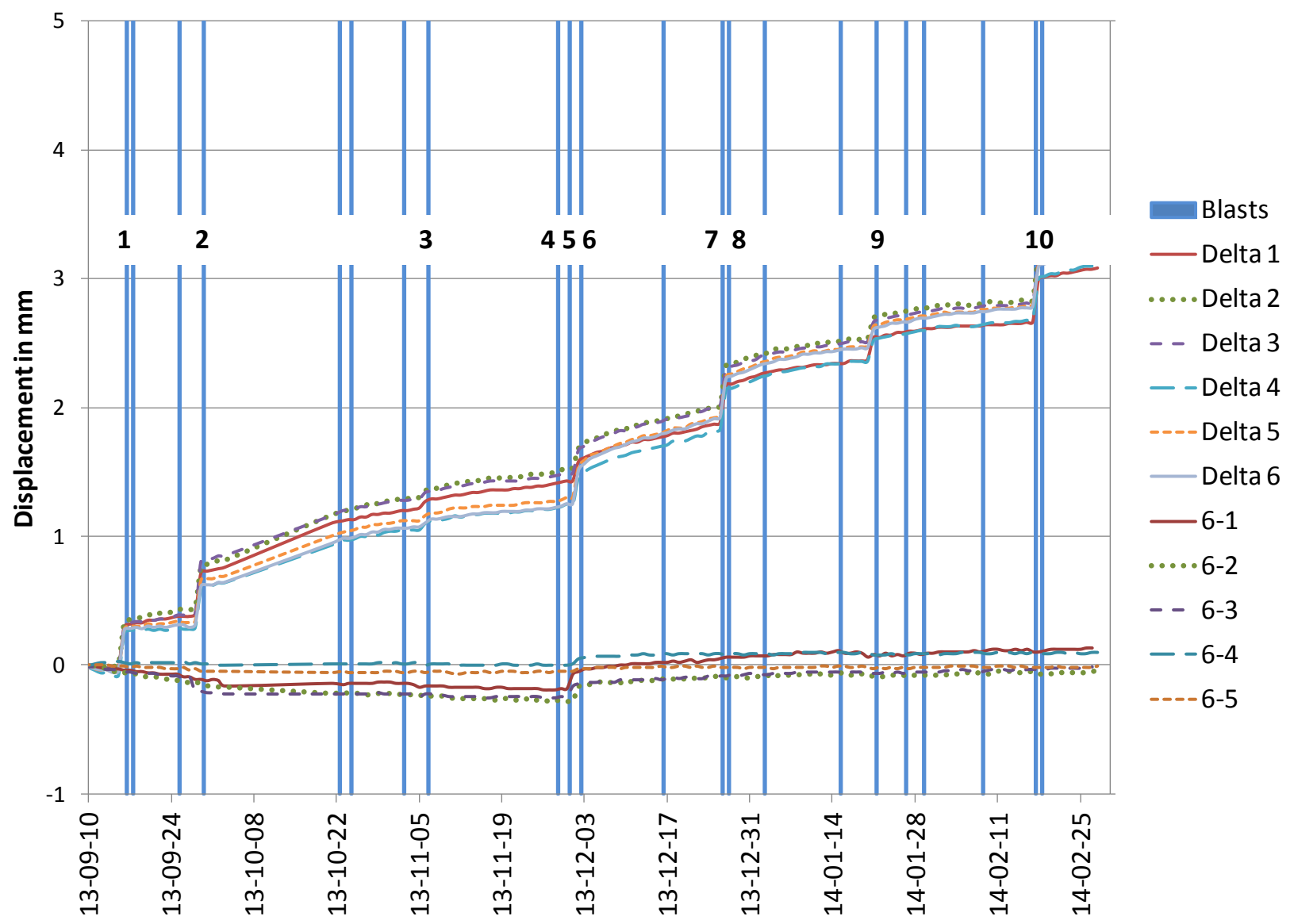

Date

Figure 9 Extensometer readings, 91-110 XC. Note change in relative slip between anchors following $M_{N} 1.0$ seismic event of 29 November 2013. Note high correlation of deformation to production blasts, up to three levels away vertically, and $120 \mathrm{~m}$ distant laterally from the instrument. No apparent response from more distant production blasts (not flagged). Anchors at 1.67, 3.33, 5, 6.67, 8.33 and $10 \mathrm{~m}$ from collar

Those instruments which cross through known moderate structures which extend towards the active stopes are also showing signs of shear, as the intermediate anchors are moving more than the shallow anchors on occasion, and not all anchors are moving in the same sense. The most significant movement has been occurring between anchors 2 and 4, which are between 3.3 and $6.7 \mathrm{~m}$ beyond the collar. Significant movement was also noted following a strong ground motion (SGM) $M_{N} 1.0$ seismic event, on 29 November 2013. 
Table 1 Blast dates for stopes influencing instrumentation in Figures 9 and 10

\begin{tabular}{cccccc}
\hline Tag & Date & Event & Location 1 & Location 2 & Comments \\
\hline 1 & 15 Sept. 2013 & Blast & $95-986$ & $87-085$ & 87 Blast on 16 Sept. 2013 \\
2 & 28 Sept. 2013 & Blast & $95-986$ & & Stope final \\
3 & 5 Nov. 2013 & Blast & $95-061$ & Slot \\
4 & 27 Nov. 2013 & Blast & $95-061$ & Slot final \\
5 & 29 Nov. 2013 & SGM event & $96-01 \mathrm{~N}$ & & Delayed burst after 95-061 blast \\
6 & 1 Dec. 2013 & Blast & $90-004$ & & \\
7 & 25 Dec. 2013 & Blast & $87-085$ & & \\
8 & 26 Dec. 2013 & Blast & $94-023$ & & First slot blast, initiated caving \\
9 & 20 Jan. 2014 & Blast & $95-061$ & $94-023$ & $95-061$ St final, 94-023 St slot toes \\
10 & 17 Feb. 2014 & Blast & $94-023$ & & Slot final blast \\
\hline
\end{tabular}

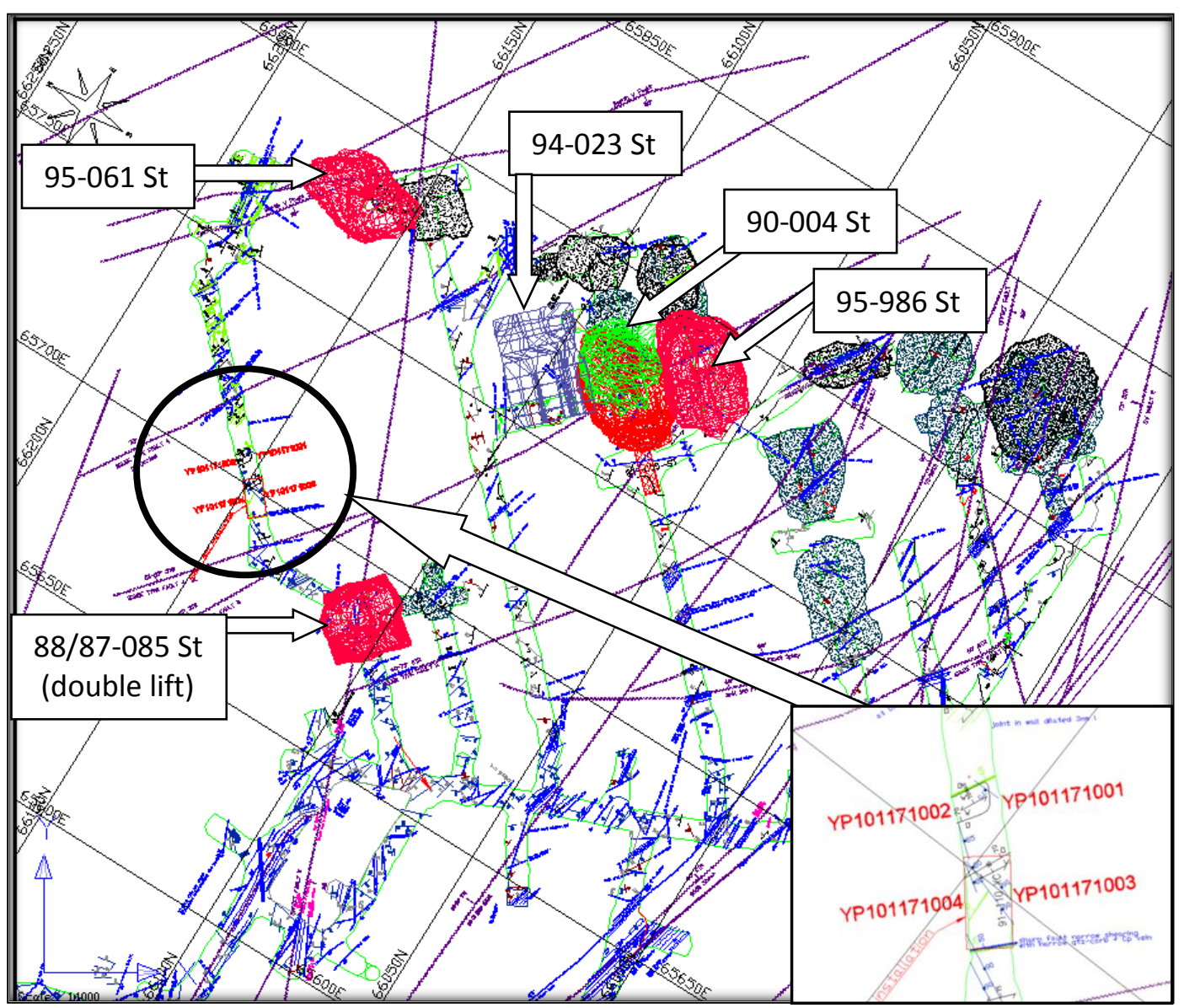

Figure 10 Location of extensometer array in 91-110 XC. Stopes influencing displacement projected to 9100 Level plan. Stope survey shown where available, otherwise blast design volume. Stopes showing most influence all lie to southeast of instruments, down strike on structure. 95-986 St filled prior to blasting 94-023 St

\subsection{Paste fill}

At the time the feasibility work was done for Mine $D$, it was recognised that the ability to fill stopes at depth in a timely fashion was critical for both the physical and economic stability of the operation. 
Historically, Kidd Mine had employed consolidated rockfill as the primary filling material. The rockfilling operations at Kidd have been extensively discussed in previous publications, (Yu \& Counter 1983; Yu 1989; McKay \& Duke 1989), however, when the Mine D feasibility study was being conducted, a number of factors indicated that a change in the filling process was required. There was insufficient rock remaining from the mining of the open pit to provide aggregate for the deeper portion of the mine. The experience within No. 3 Mine indicated that attrition of the aggregate particles as they were transported to depth through the rockfill raise network would mean that a larger percentage of the fine material in the aggregate (as it was prepared on surface) would need to be removed to ensure a workable material would be delivered to the stopes at depth. A significant portion of the rock used in the fill within No. 3 Mine was already comprised of direct unsized development waste from the lower portion of the workings, as well as some of the early infrastructure (ventilation raises) being developed in advance of Mine D. It was also recognised that the rather lengthy process of tramming waste fill to the stopes could also negatively impact both productivity and stability of the openings.

A paste fill system was investigated in the pre-feasibility and feasibility stages, and was ultimately commissioned in 2004. The paste fill aggregate component was comprised of a blend of alluvial sand from local esker deposits (50-55\% by mass), and reclaimed tailings from neighbouring gold mines within Timmins ( $45-55 \%$ by mass) to provide the necessary $-20 \mu \mathrm{m}$ fraction required to make a paste. The distance of the Kidd Metallurgical complex from the mine, and the nature of the Kidd tailings, (which contained high levels of pyrite and which were prone to oxidation and the associated creation of low pH conditions) forced an alternate fine constituent source to be found for the manufacture of the paste. At the same time, the occasional presence of low $\mathrm{pH}$ water associated with very high sulphide ores, and the results of early stage laboratory testing with the Kidd tails resulted in the selection of a ground iron blast furnace slag and Type 10 ordinary Portland cement (OPC) blend (90:10 slag to OPC) for use in the Kidd paste fill. The decoupling of the filling preparation process from the mining process, and the higher rate of placement which could be achieved around the clock also favoured the use of paste fill (Landriault et al. 2000).

Binder is added at between 4.5 and $2 \%$ by weight of the aggregate components, depending on the design criteria of the stope in question. Sill stopes, which will be undercut by future mining are filled with a $4.5 \%$ binder base to half the depth of the stope (equal to the future minimum undercut span or $20 \mathrm{~m}$ above floor elevation), followed by a mains pour comprising $2.5 \%$ binder until the stope is full. Secondary panels, and blocks which will not be undercut are filled with a small $4.5 \%$ binder plug pour to reduce the risk of bulkhead failure (to $7 \mathrm{~m}$ above floor elevation), followed by the mains pour which may contain as little as $2 \%$ binder, if the fill will not be exposed by future mining. Strengths generally range from 2 to $4 \mathrm{MPa}$ after between 28 and 90 days of curing. The paste is typically poured at a solids density (mass of solids divided by total unit mass of paste) of $82 \%$.

As the use of paste fills gained acceptance within the general mining industry over the course of the last 15 years, the need to obtain fundamental engineering information has led to several research initiatives by a number of universities, in conjunction with industry. In 2008, a major research initiative was undertaken with the University of Toronto, to measure the properties of paste fill at early ages. This work was initiated to confirm the underlying assumptions relative to the design of stope bulkheads, and to investigate the potential for paste fill to liquefy at very early curing times. Work was also done at both the Williams Mine (Barrick Gold Corporation) in Marathon, Ontario, and at the Cayeli Mine (Inmet Mining Corporation) in Turkey, as part of the same research program. The results of that work will not be described in detail, and several references are provided to that work, and to other papers previously published (Thompson et al. 2009, 2014; Aldea et al. 2011).

An unexpected but fortuitous outcome of the extensive instrumentation program associated with the University of Toronto was that a limited number of the low range $(500 \mathrm{kPa})$ total earth pressure sensors installed to monitor the short term behaviour of the paste were still functioning at the time of the significant seismic event in January 2009. The excitation circuit for the vibrating wire readout was changed midway through the monitoring process to try to extend the life of the cells, however most failed at pressures approaching $1 \mathrm{MPa}$. In those cells which remained functional 6 months after installation, the 
strain induced by the $M_{N} 3.8$ burst resulted in changes in the induced stresses measured within the paste fill which were of similar or larger magnitude to those which occurred due to the closure associated with the removal of the overlying stope.

\section{7-SL1 Stope Fill Pressure Data - Cages 1 and 2}

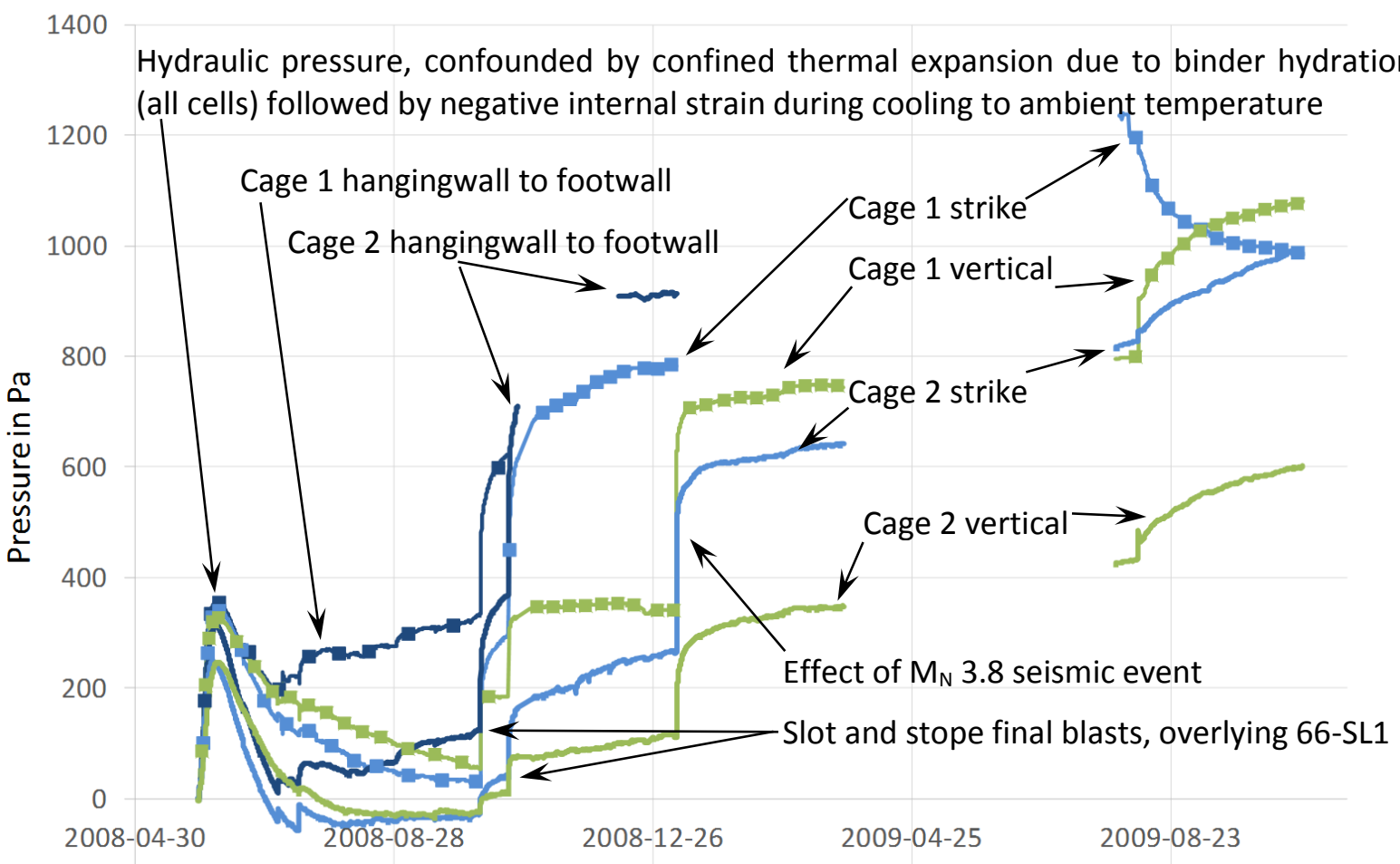

$$
\rightarrow \text { Cg1 HWFW } \rightarrow \text { Cg1 Strike }- \text { Cg1 Vert }-\mathrm{Cg} 2 \mathrm{HWFW}-\mathrm{Cg} 2 \text { Strike }-\mathrm{Cg} 2 \text { Vert }
$$

Figure 11 Total Earth Pressure cell data, 67-SL1 Stope. Cells measure stresses orthogonally normal to the hanging wall, parallel to strike, and vertically. Traces from the three cells in Cage 1 are shown with data markers for clarity. Cage 1 located just within hanging wall of stope; Cage 2 located just inside brow. Block above the instrumented stope was blasted 7 and 20 October 2008, resulting in abrupt change in all cells. Cells measuring hanging wall-foot wall failed during the final blast in $66-S L_{1}$ St. $M_{N} 3.8$ burst 6 January 2009 resulted in abrupt change in stress. Missing data from March to August 2009 due to temporary removal of the data logger to allow development of adjacent stope

As shown in Figure 11, after the cessation of the thermal effects of paste curing, (Thompson et al. 2014) the cells oriented parallel to the hanging wall and foot wall showed the most change as the stope immediately above the instrumented fill was mined, causing closure. Those cells failed on overpressure early in the monitoring programme. During the $M_{N} 3.8$ seismic event, of the remaining active stress cells, those measuring the change in stress sub-parallel to the strike direction of the slip surface showed the most change. This is to be expected as the slip vector associated with the $M_{N} 3.8$ event was confirmed through surveying of original drift stations to be oriented sub-parallel to the break plane (dextral strike slip), hence compression of the fill due to the deformation associated with the event would have the most influence on these cells. Changes in stress could also be observed in a second instrumented stope located over $500 \mathrm{~m}$ below the epicentre, in the south abutment on the 8800 Level. Further work is to be undertaken to instrument other stopes with a limited number of much higher range total earth pressure cells (currently specified at 7.5 MPa nominal capacity), in order to extend the monitoring period available prior to cell failure, and to determine if changes in the deformation of the fill can be used as a reliable analogue for deformation of the surrounding host rock, as an aid to calibration of the stress models. 


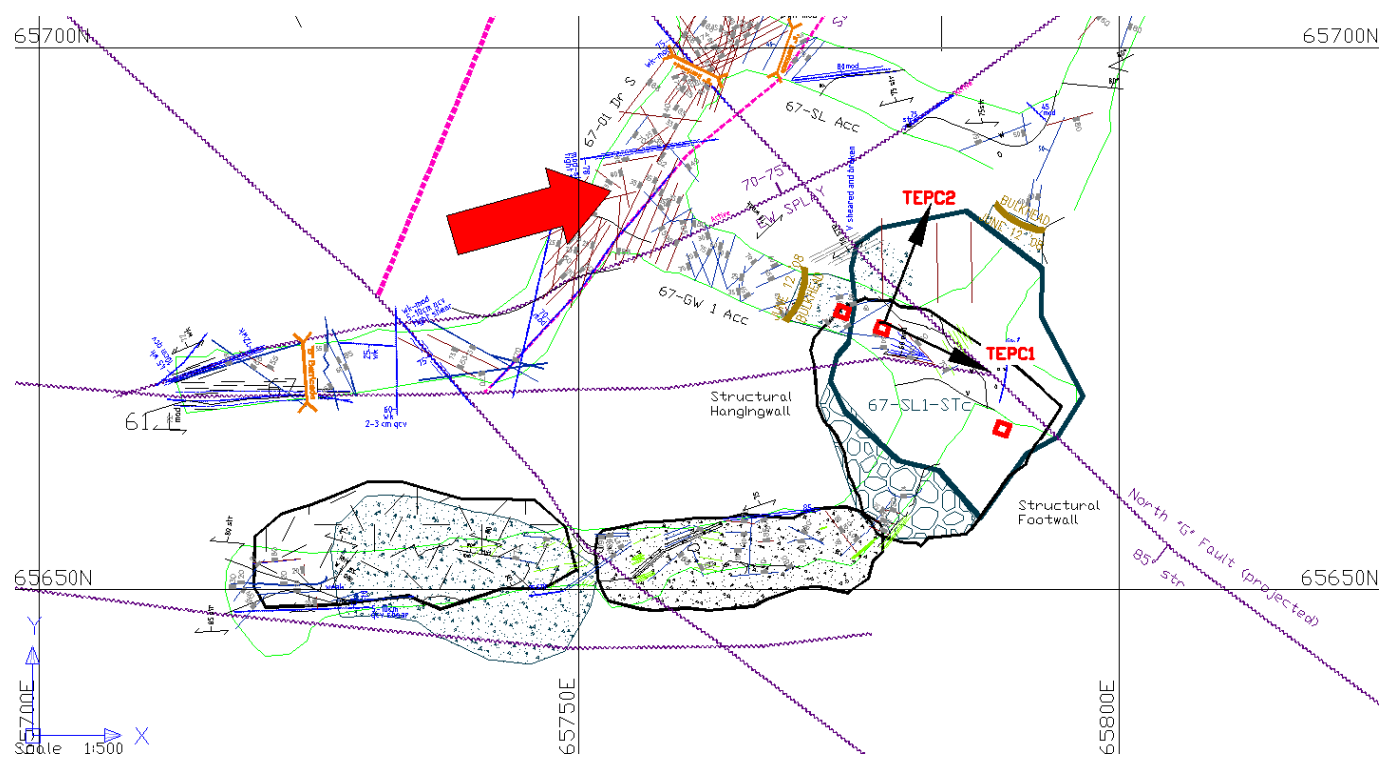

Figure 12 Plan view of 67-SL1 Stope showing location and orientation of instruments 1 and 2 in each cage (TEPC 3 measures vertical load). Cage 1 is closest to the stope hanging wall, and Cage 2 was located in the access drift, under the brow. Cage 2 would be subject to less regional deformation, as it was essentially located within the rock mass, while Cage 1 was substantially surrounded by fill. Large arrow indicates approximate far field slip direction of foot wall during $M_{N} 3.8$ seismic event, 6 January 2009

In addition, triaxial testing with volumetric strain measurements will be done on samples of paste fill at much higher confining pressures than was done at the system design stage, (where the maximum confining pressure was limited to $700 \mathrm{kPa}$ ), in order to understand the strain associated with the measured stress changes from the initial University of Toronto studies, and to provide data for comparison with the output from the new higher range total earth pressure cells which are to be installed in select stopes. The current plan being developed, in conjunction with the University of Toronto is to test the paste in stages to confining pressures approaching $5 \mathrm{MPa}$. Drained and undrained consolidation testing is also planned, to better understand the volumetric strain of the paste due to loading.

\section{Environmental challenges}

With ever-increasing depth, the ventilation system has undergone major changes over time. Originally, air was supplied to levels from the shaft stations through 1.5-2.1 m diameter fans, with motors up to $190 \mathrm{~kW}$. Every level had supply provided via internal fresh air raises and return air was directed to the main exhaust raises at the extreme abutments of the orebody via 1.5-2.1 m fans, identical to the station supply fans. The main exhaust raises terminated on surface, or in the open pit walls. In the late 1990s, with the increasing depth of No. 3 Mine, a dedicated new exhaust raise was driven from the 4700 Level to the 1600 Level, and a large booster fan was installed to create negative pressure to assist the local level exhaust fans. This raise was located above the upper extension of the future No. 4 Shaft. Once Mine D was approved, an additional dedicated ventilation shaft was sunk from surface to the 1600 Level to tie in with the new raise underground, and two $2.6 \mathrm{MW} 3.35 \mathrm{~m}$ diameter exhaust fans were installed on the collar of the shaft. As the Mine D project advanced, additional exhaust raises were driven at depth, and two $2.9 \mathrm{MW} 3.35 \mathrm{~m}$ diameter booster fans were installed on the 6000 Level to augment the dedicated exhaust fans on surface. During the conversion to an exhaust-driven ventilation system, the majority of the supply fans at the shaft stations, and all of the exhaust fans on the levels, save those impacted by the high pressure discharge of the booster fans on 6000 Level, were taken out of service. As extraction ceased on old levels in the upper portions of the mine, services were decommissioned and the exhaust raise accesses were sealed to improve the overall efficiency of the ventilation system. 
In the mid 1990s, increasing adiabatic compression due to depth resulted in significant heating of the fresh air. In order to improve the working conditions in No. 3 Mine, a passive cooling system was created, utilising several hundred metres of rubble which had filled the last stopes mined below the bottom of the open pit. Dedicated ventilation raises were driven, and connected to existing lateral development in the foot wall of the upper mine, which also connected to the mined out pillars. The remainder of the levels not connecting with the rubble were isolated from the new inlet system, and the fresh air raises were extended to depth, ultimately connecting with the top of the No. 3 Shaft. Cold air, averaging $-24^{\circ} \mathrm{C}$ and which can reach temperatures of $-45^{\circ} \mathrm{C}$ overnight in winter, was drawn through the rubble by a pair of dedicated $1.4 \mathrm{~m}$ diameter $186 \mathrm{~kW}$ fans on the 2800 Level. This subsequently chilled the rubble to temperatures of approximately $-10^{\circ} \mathrm{C}$, and warmed the air to temperatures of around $-5^{\circ} \mathrm{C}$. Warm air which averages $+25^{\circ} \mathrm{C}$ would be drawn in through the rubble, which would then chill the air, yielding a mean outlet temperature of between 5 and $10^{\circ} \mathrm{C}$ over the course of the summer. As shown in Figure 13, in the spring, snow melting from, and precipitation falling into the pit would infiltrate the rubble, and flash freeze upon hitting the very cold rock mass. This ice would then also contribute to chilling of the air until it melted in approximately late May or early June. The bulk of the thermal mass providing the heat transfer is the chilled rock, and the system has been estimated to provide between 5 and $9 \mathrm{MW}$ of refrigeration, depending on the average winter temperature. This system was subsequently expanded with the start-up of Mine $D$, by connecting several more levels into the raise system, down to as low as the 1600 Level, and a new connection was made to the No. 1 Shaft, allowing cold air to be directed into the shaft. A new ventilation raise was excavated from the bottom of the No. 1 Shaft, ultimately connecting to the No. 3 Shaft at the 4700 Level. Both the No. 1 and 3 production shafts were decommissioned and converted into dedicated fresh air conduits as part of the Mine D project.

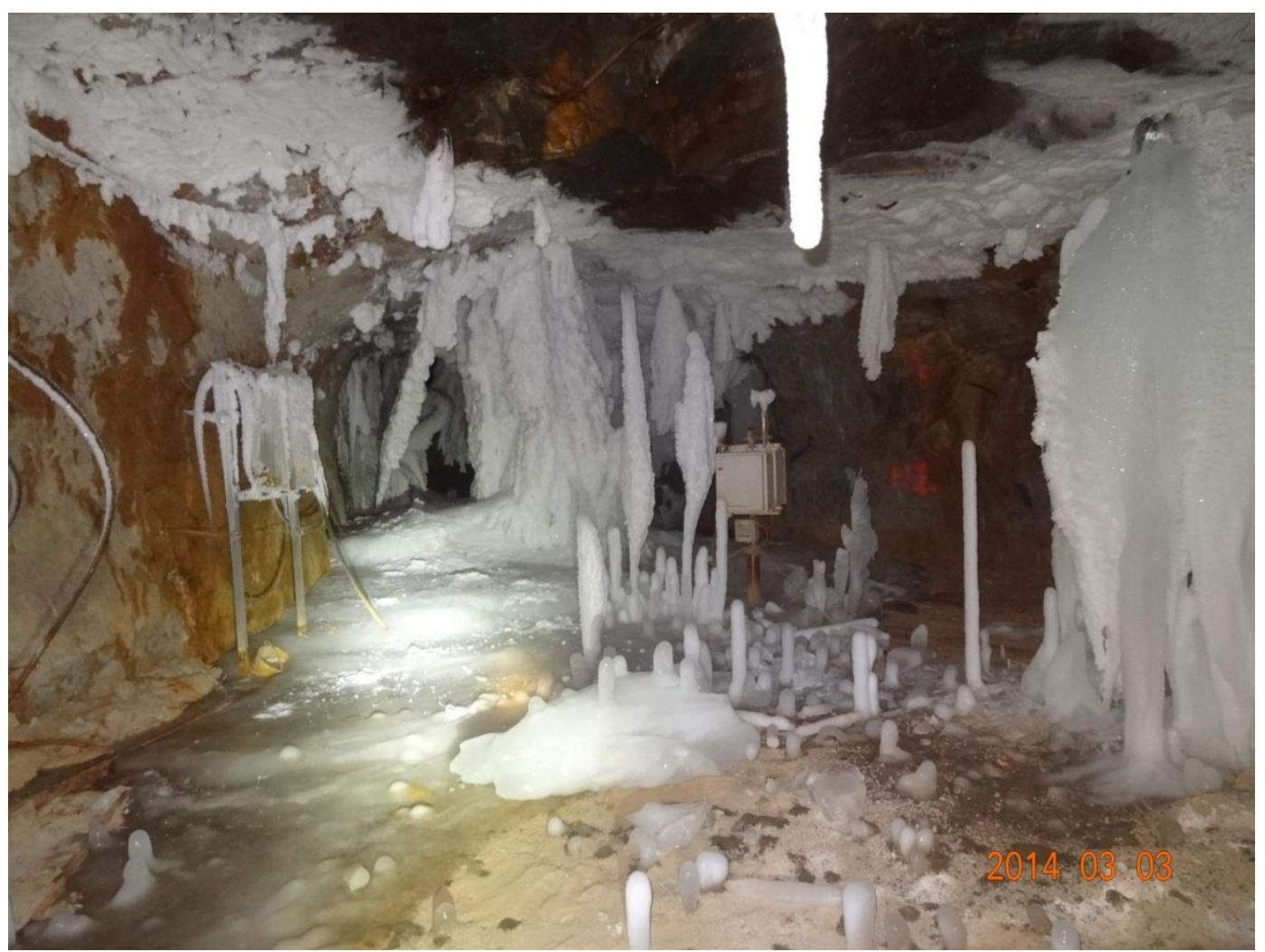

Figure 13 Ice accumulations in access to cold stope, 1200 Level collector drift, 3 March 2014

In addition to the expanded cold stope, a refrigeration plant and bulk air cooler were constructed on surface, to supplant the chilling supplied by the cold stope. The ammonia based plant utilises a $1.3 \mathrm{MW}$ screw compressor, and provides $7.5 \mathrm{MW}$ of refrigeration by supplying chilled water at approximately $6^{\circ} \mathrm{C}$ to a bulk air cooler installed at the collar of the No. 1 Shaft. In the winter, the bulk air cooler is taken offline, and ambient air is drawn directly into the mine through the collar house. This ultra-cold air also cools the 
No. 1 Shaft walls, and all lateral connector drifts to at least the 3800 Level, which also results in the creation of additional ice in the spring freshet.

Through the combined effects of the bulk air cooler and the cold stope system, air temperatures generally remain near $22^{\circ} \mathrm{C}$ wet bulb (WB) at the exit of No. 4 Shaft at the 9600 Level. In the summer, the bulk air cooler reduces the ambient air inlet temperature to around $+10^{\circ} \mathrm{C}$. When combined with the cooler air exiting the cold stope on the 1600 Level, significant cooling is achieved. This air warms substantially under the increase in pressure to depth, but still results in temperatures in the mid twenties ${ }^{\circ} \mathrm{C}(\mathrm{WB})$ at the bottom of the mine. Without benefit of cooling, WB temperatures in the mid to high thirties ${ }^{\circ} \mathrm{C}$ could be anticipated.

\section{$4 \quad$ Other challenges}

Due to the weak and strongly structured nature of the rock mass, and the high stresses at depth, other issues continue to cause challenges to the operations. Crushing and caving of production blastholes and slot raises due to the high rates of convergence, as shown in Figure 14, have resulted in several operating changes. Most recently, sacrificial raises have been bored several weeks to months in advance of the primary slot raise for stopes in the abutments, and in the hanging wall of primary panels at depth. The first raise is given time to yield, which effectively de-stresses and fails the ground, allowing the second raise to be drilled with less difficulty.

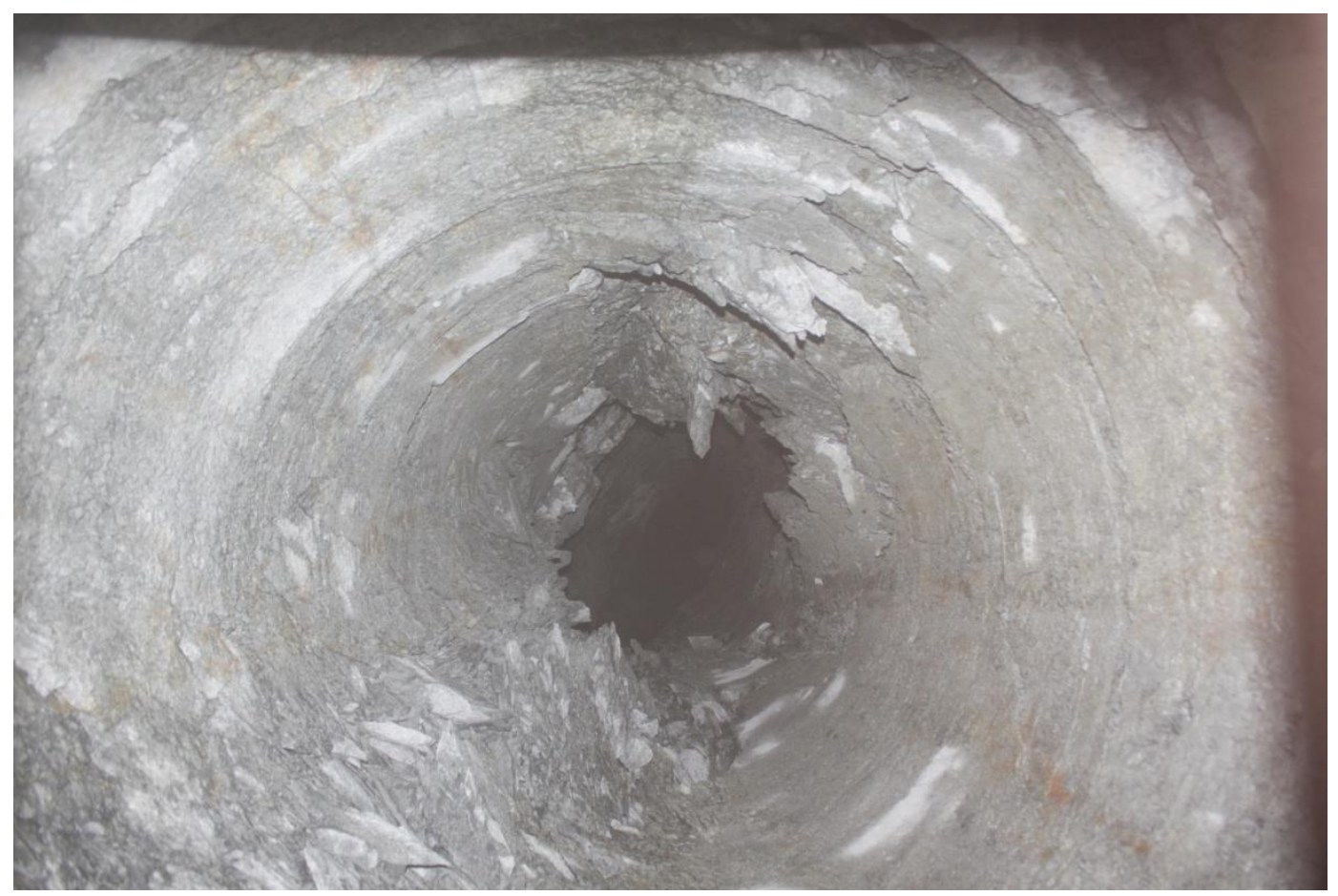

Figure 14 Early stages of breakout in reamed slot raise, 91-040 Stope

This also provides enough strain relief to reduce the crushing of the primary blastholes around the slot to tolerable levels, although as the ground is highly fractured, caving becomes a secondary concern. Where the ground is so failed that raises cannot be reliably excavated, stopes have been mined by drilling shallow rings of holes from well outside the stope boundary, and 'slapping down' the ore in sub horizontal slices into the open undercut below. Once the inclination of the holes is such that the break angles no longer allow blasting from the undercut elevation, similarly oriented holes are drilled from outside the stope boundary on the overcut, allowing the sub horizontal slicing to continue to the overcut. This same approach has been used in areas where access is not possible due to the high levels of damage incurred during the major bursting of the last five years. 


\section{$5 \quad$ Summary and thoughts for future work}

As mentioned previously, work is ongoing with various research groups to provide more fundamental data to assist with the interpretation and calibration of the stress models, to better understand the response of the paste fill to high strain induced by hanging wall to foot wall closure, and to assist with the formulation of new design codes for support systems in dynamic environments by providing large quantities of data to use in back analysis.

Areas for future research or development of existing systems or instruments, which would be beneficial to the industry in general, include the calibration of changes in seismic velocity as determined by passive tomography to actual changes in rock mass properties brought about by deformation or degradation. A reliable and low cost means of measuring global deformation of the host rock mass to mine scale is also necessary which is independent of local deformation of the excavation surfaces, with independent frames of reference, as frequently main infrastructure such as the shaft or main access ramp or level connection to the shaft is also located within the deformation zone. The development of low cost pressure or strain cells, which could easily be deployed in nearly every stope during filling, would also be advantageous. With the rapid development of underground network technology, linking these measuring devices wirelessly, even though the fill, would be a long term goal.

Another area where significant work has been done recently, but where questions still arise is in the testing and design of support under high dynamic loads. Many new bolts have recently been developed to address the issue of dynamic loading, including the D Bolt (Li 2010, 2012), the Yield Lok Bolt (Wu \& Oldsen 2010), and others, and extensive test work continues to be done both in Canada and Australia to assess these tendons (Doucet 2012). One of the limitations of the dynamic test facilities has always been the nature of the loading applied to the bolts during the impact phase. Evidence from the multiple $M_{N} 3.8$ events at Kidd, and experience from other sites has shown that the bolts undergo significant lateral loading causing both bending and shear as either static loading, or components of the seismic waves from a large event pass through the rock mass (Simser et al. 2006), in addition to the axial loading ultimately imparted to the tendon as the rock mass swells due to the development of fractures and the support membrane transfers load to the end attachments of the bolt. See Figure 15. This is one area where continued development of the physical testing process would be advantageous, through either sinusoidal guide rails or transverse secondary servo mechanisms, or if this is not plausible, then kinematic model simulations need to be developed to improve the basic understanding of support response, in order to improve the design process. Another area requiring investigation would be a means of verifying the integrity of the support tendons, 1-2 $\mathrm{m}$ beyond the rock surface, following large seismic or high displacement events. Preparing every bolt by polishing the end for non-destructive ultrasonic testing to find fractures or strained portions of the bar is not practical, and based on the observations (as shown in Figure 15), bolts which appear to be intact when examining the plate and head can be sheared completely through, as little as $1 \mathrm{~m}$ beneath the rock surface. Similarly, installing deformation monitoring instrumentation at a frequency such that it could be used to verify bolt integrity over multiple kilometres of development is also not cost effective or practical.

In summary, both the operators and engineers at Kidd have continued to adapt to the challenges of extending the workings to depths of $3 \mathrm{~km}$ and more, however, there continue to be opportunities for the advancement of basic knowledge, and new technologies are still required to continue to improve both the safety and viability of mining in deep and high stress environments. 


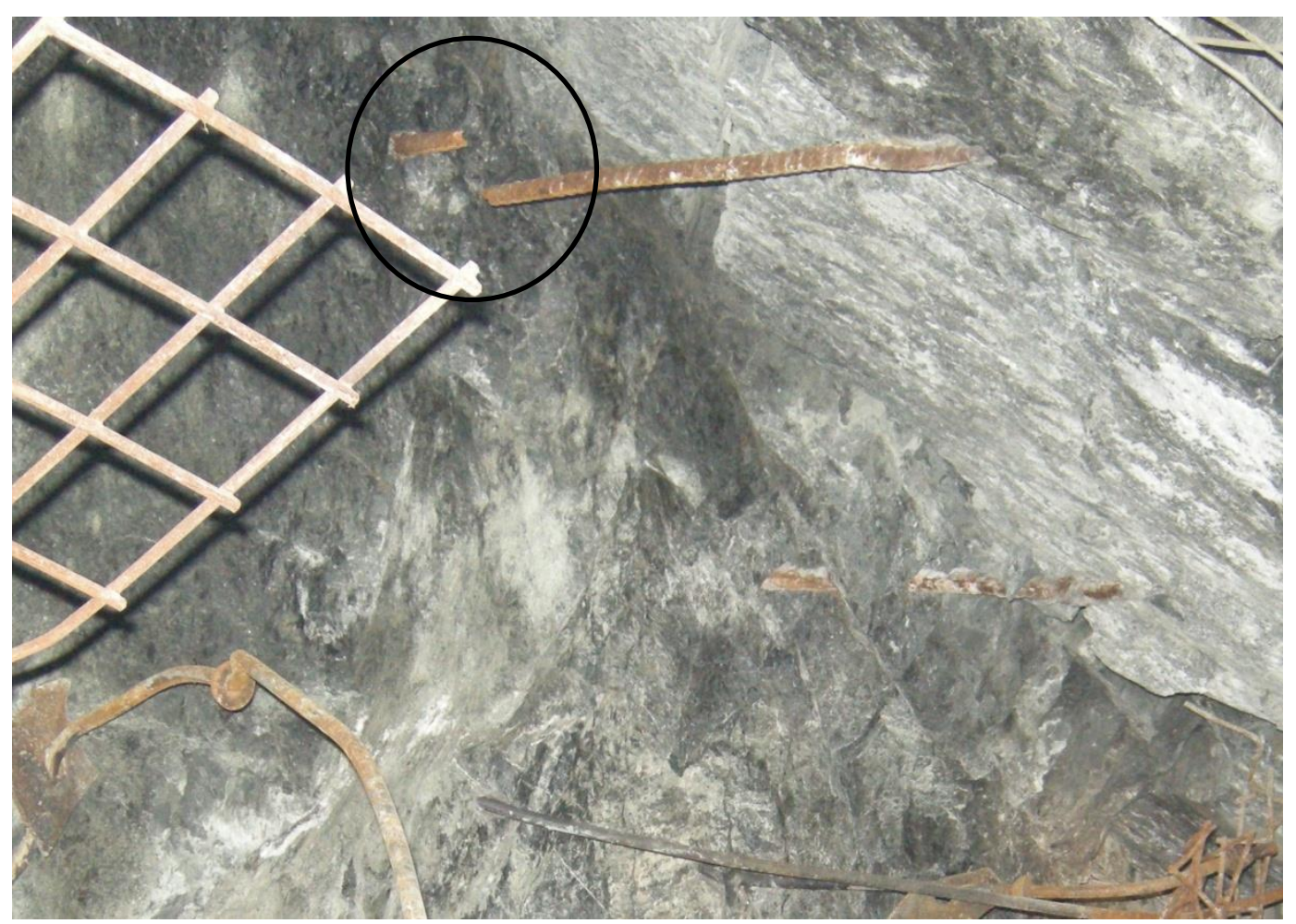

(a)

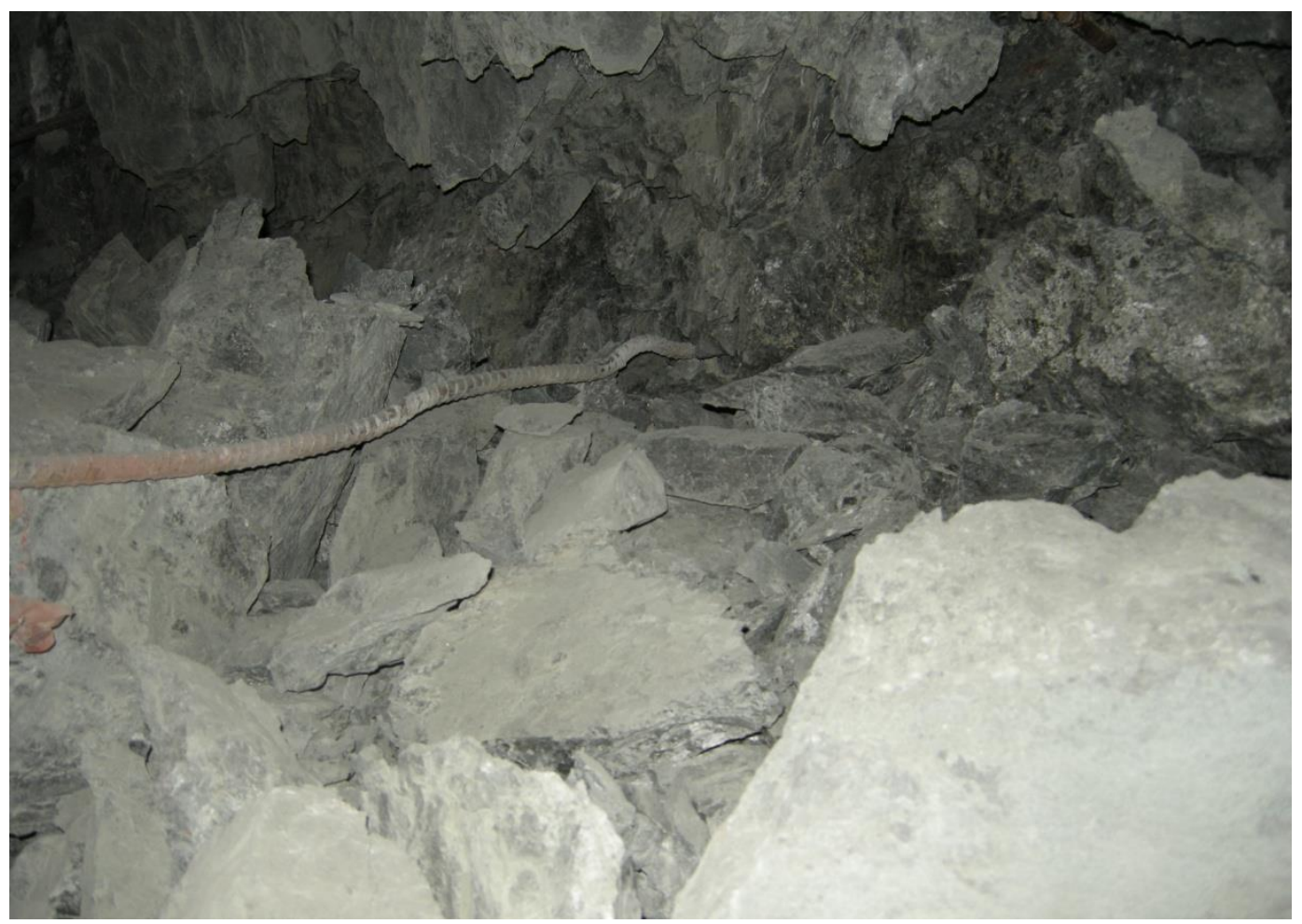

(b)

Figure 15 (a) sheared rebar through rupture trace, with minor undulations near intersection with rock surface and no damage apparent at plate, 70-82 XC entrance; and (b) undulation imparted in $22 \mathrm{~mm}$ rebar by transverse vibrations occurring within the rock mass prior to ejection, 70-82 XC, both following $M_{N} 3.8$ burst, 6 January 2009. This type of deformation resulted in the lock up and failure of adjacent MCB 33 cone bolts. Image 


\section{(a) is of the same area shown in Figure 4, after the removal of the pulverised rock. The strong joint bounding the upper failure surface is visible in the centre right of Figure 4}

\section{References}

Aldea, C, Cornelius, B \& McGuinness, M 2011, 'Kidd Mine paste fill binder research study' in RJ Jewell \& AB Fourie (eds), Proceedings of the 14th International Seminar on Paste and Thickened Tailings, Australian Centre for Geomechanics, Perth, pp. 505-516.

Board, M, Seldon, S, Brummer, R \& Pakalnis, R 2000, 'Analysis of the failure of a large hangingwall wedge: Kidd Mining Division, Falconbridge Ltd.', CIM Bulletin, vol. 93, no. 1043, pp. 89-97.

CANMET 1977, Pit Slope Manual, (10 chapters plus supplements), CANMET Report 77-41, Canada Centre for Mineral and Energy Technology, Natural Resources Canada, Ottawa.

Disley, N 2014, 'Seismic risk and hazard management at Kidd Mine', in M Hudyma \& Y Potvin (eds), Proceedings of the Seventh International Conference on Deep and High Stress Mining, Australian Centre for Geomechanics, Perth, pp. 107-122.

Doucet, C 2012, Ground Support Research at CanmetMINING, presented at Workplace Safety North (WSN) Symposium on Dynamic Ground Support Applications, Sudbury, September 13 2012, viewed 30 June 2014, http://www.healthandsafetyontario.ca/HSO/media/WSN/Resources/WSN-2012-C-Doucet-Ground-Support-Research-atCanmetMINING.pdf

Landriault, D, Brown, R \& Counter, DB 2000, 'Paste backfill study for deep mining at Kidd Creek', CIM Bulletin, vol. 93, no. 1036, pp. 156-161.

$\mathrm{Li}, \mathrm{CC}$ 2010, 'A new energy-absorbing bolt for rock support in high stress rock masses', International Journal of Rock Mechanics and Mining Sciences, vol. 47, pp. 396-404.

Li, CC 2012, 'Performance of D-bolts under static loading', Rock Mechanics and Rock Engineering, vol. 45, issue 2, pp. $183-192$.

McKay, DL \& Duke, JD 1989, 'Mining with backfill at Kidd Creek No. 2 mine', in FP Hassani, MJ Scoble \& TR Yu, (eds), Proceedings of the 4th International Symposium on Mining with Backfill, A.A. Balkema, Rotterdam, pp. 161-172.

Simser, B, Andrieux, P, Langevin, F, Parrott, T \& Turcotte, P 2006, 'Field Behaviour and Failure Modes of Modified Conebolts at the Craig, LaRonde and Brunswick Mines in Canada' in Y Potvin, J Hadjigeorgiou and D Stacey (eds), Challenges in Deep and High Stress Mining, Australian Centre for Geomechanics, Australian Centre for Geomechanics, Perth, pp. 347-354.

Thompson, BD, Grabinsky, M, Bawden, W \& Counter, D 2009, 'In situ measurements of paste backfill in long-hole stopes', in M Diederichs and G Grasselli (eds), Proceedings of the 3rd CANUS Rock Mechanics Symposium, Toronto, on CD-ROM.

Thompson, BD, Simon, D, Grabinsky, MW, Counter, DB \& Bawden, WF 2014, 'Constrained thermal expansion as a causal mechanism for in situ pressure in cemented paste and hydraulic backfilled stopes', in Y Potvin \& TG Grice (eds), Proceedings of the 11th International Symposium on Mining with Backfill, Australian Centre for Geomechanics, Perth, pp. 365-378.

$\mathrm{Wu}, \mathrm{R}$ \& Oldsen, J 2010, 'Development of a new yielding rock bolt - Yield Lok bolt', in 44th US Rock Mechanics Symposium and 5th US-Canada Rock Mechanics Symposium, vol. 2, American Rock Mechanics Association, Alexandria, pp. 1378-1383.

Yu, TR \& Counter DB 1983, 'Backfill practice and technology at Kidd Creek Mines', The Canadian Mining and Metallurgical Bulletin, vol. 76, no. 856, pp. 56-65.

Yu, TR 1989, 'Some factors relating to the stability of consolidated rock fill at Kidd Creek' in FP Hassani, MJ Scoble \& TR Yu (eds), Proceedings of the 4th International Symposium on Mining with Backfill, A.A. Balkema, Rotterdam, pp. 279-286. 